\title{
An Extravagant Depiction of the Human World: Through the characters in The Mahabharata and The Iliad.
}

\author{
Pankhuri Aggarwal
}

PhD Research Scholar, Dept. Of English, University of Jammu, India

\begin{abstract}
.
Literature is fixed in time and space. However, works of literary merit gain universality and timelessness. Epics such as the Mahabharata and the Iliad are creative works that have surpassed the test of time. They have combined the timeless and the universal together, creating a tradition and a history that holds valid even after centuries. Both the epics are the fossils of civilization, more audacious and challenging than other epics written. They are historical artifacts providing answers to the questions of our existence. These stories edify the ethical values, customs, rituals and traditions of their respective societies. Both exhibit the impulses of the human spirit in intense forms. The two epics appeal to hearts and minds by their concern for human persona, nature, potentialities, the consequences of passion and desire for honour. Both the texts create a spectacular picture of the human world, through the portrayal of characters that have remained etched in memory. The paper will focus on a comparative analysis of the characters of the Mahabharata namely: Indra, Draupadi and Arjuna and the characters of the Iliad: Zeus, Helen and Achilles, respectively, each exhibiting common human sentiments. The characters of the Mahabharata and the Iliad are recognizable and understandable specimens of humanity in all its essential magnificence. A comparative analysis reveals that despite cultural gaps human beings share certain common tendencies and emotions. Thus analyzing the two epics, one from the eastern and the other from the western culture, the paper will highlight the commonalities between the characters of the Iliad and the Mahabharata.
\end{abstract}

Keywords: Universality; Timelessness; Ethical values; Rituals; Comparative Analysis 


\author{
21 - 23 JUNE $2019 \quad$ VIENNA, AUSTRIA
}

Mythologies have always had a great impact on the human societies across the world and on the literature produced by these societies. According to Robert Graves, an eminent mythology critic, "Mythology has two main functions. The first is to answer the sort of awkward questions that children ask: who made the world? How will it end? The second function of myth is to justify an existing social system and account for traditional rites and customs" (12). Prominently, mythologies define the validity of human existence in society. Mythologies play an important in shaping human actions, thoughts and their literary significance.

The importance of the study of mythology today rests on the fact that men everywhere and at all times face the same basic problems and ask the same questions. People want to know why they are and what they are, why nature behaves as it does and how cause and effect are interlinked. Questions of this nature seek answers from such studies which might help arrive at some explanation of the 'how and 'why' of the universe. "Myth is at varying levels of consciousness and degrees of articulateness, a way of describing the foundations of social

behavior" (Righter 10).

Mythological storytellers both past and present believe that reality is too complex to grapple, so they rely profoundly on such stories that provide a glance of that complexity; by pointing at various concealed mythic realism concerning common people, place, things and events. Mythical storytellers of ancient Greece told about ancient events like the Trojan War, and about supernatural beings like Zeus and other deities believed to dwell on remote Mount Olympus. It is certainly realized by the spectators that these narratives of Trojan heroes and Olympian deities could not have been seen. Yet they seem to feel that stories like those of Troy and the Olympians unite furtively to the common realities of warfare, and to the invisible influence of supernatural powers on their daily lives. The ancient peoples of the Middle East, likewise, told stories now recorded in the Hebrew Bible, the New Testament, the Mahabharata, the Ramayana and the Qur'an. Admitting not only direct connection with God, angels or the demons; but feel a strong mysterious existence of divine and demonic beings.

Mythic stories typically depict more realistic experiences of hardship and struggle that are part of widely accepted historical narratives. For instance, Greek warriors of the ancient Mediterranean experience the rage and errand of the Olympians while at sea and on the actual battlefields; Moses, Jesus, Mohammad, Krishna and their followers similarly reveal their intrinsic worth which was documented during that periods and created history. "Modern scholars of mythology, tend to argue that the accuracy of the details told in these stories has never really mattered much to those who tell and listen to mythological stories. What matters more, such sympathizers claim, are the powerful symbols and messages conveyed by those stories" (Dubois). 
A comparative or cross-cultural study of world religions, Huston calls "a voyage in space and time and eternity" (1). Cross-cultural comparisons of the world's historical myths, "have revealed remarkable similarities in themes, structures, images, and characters...in the types of phenomena they seek to elucidate and the types of questions they address" (Myth 284). These cross-cultural similarities raise confrontational queries: Do certain universal myths, systematize and unite the mythic narratives and their literary forms across diverse cultures across the world? Why are there such similarities? Do all human beings inherit unconsciously, common forces, prototypes and propositions? Thus, these stories have acquired a prominent place in human history and later on, they have taken a permanent place in the human heart and mind. "The study of comparative mythology need no longer be looked on as an escape from reality into the fantasies of primitive peoples, but as a search for the deeper understanding of the human mind" (Davidson 1).

The Comparative Mythology study testifies to the truth that the works exist and are understood only in unity and not in isolation. Not merely analogies even contrast traced between authors and literary traditions help towards a greater understanding of the works. A juxtaposition of them illustrates the points of strength as well as weakness. "Many of the striking analogies that appear in these studies may, of course, be traced to common human experience and to the consequences that flow from any attempt to mould the raw material of life into the formal perfection of the lyric poet's art" (Prawer 55). Such similarities are the archetypes of human imagination and these arise due to the common ways of the response of the human mind to common experience. It is a natural instinct in man to understand these essentially similar responses by comparisons and contrasts.

The epics like the Mahabharata and the Iliad share larger areas of common interest. Both the epics are two variations on a common human theme and studied in the background of the cultural movements that produced them. They have a definite place in the evolution of forms and the history of ideas and the comparative study helps to view them at once in their particular time and place and in their ability to rise to be universal.

Thus, a common objective of the art of this kind calls for a comparative study in depth, of their poetry, image complexes and theme patterns which the Mahabharata and the Iliad share. Both are astonishingly alike in being the primal poems and the first poetic visions of the situation of man and every later poem are but a refinement or reduplication of the glory of the first vision. The tragic vision of man and nature embodied with the same compulsiveness in both Ved Vyasa and Homer brings them together into a common brotherhood. They work through a common mode and bring out with all the force of their poetry the primal innocence of man and the maturity. The two great epics documents the state of man, stand as comer stones of the two cultures of the West and the East and they rise beyond their immediate milieu as towering symbols of the human spirit.

The Mahabharata is believed to have been composed between 200 BCE and $200 \mathrm{CE}$ and is said to be "the longest epic in history. It's writing is followed by the 'Kali Yuga', which was a period of retrogression in which families were waging war" (Rodrigues 227). 
The 'Maha' in the title the Mahabharata indicates the text size and tendency 'to refuse to be circumscribed by any singular perspective- that is, it's being consciously and blatantly intertextual' (Huberman 151-52) and 'Bharata' indicates India itself. It stands as an epitome of greater India and can be called 'the quintessence of everything that is Indian' (Sanyal 197).

All the subjects and themes in the Mahabharata oscillate between two threads viz. (i) the conflict between the Pandavas and the Kauravas and (ii) dialogues on all aspects of dharma. These two threads are a variable pattern of interrelationships among the characters embedded in the narratives of the epic. The narratives and the epic itself are interwoven and complexly structured, and significantly, serves as drstanta for the four ends of life- dharma, artha, kama and moksha. This intricate structuring is an enigma for an epic scholarshipIndian or western.

The epic has suffused all aspects of Indian life as it has been sung, recited and retold in various genres and ways "poets have told it before, poets are telling it now, other poets shall tell this history on earth in the future" (Ganguli 6). It has been translated into all major Indian languages including tribal languages. Moreover, there have been translations into languages like English, Russian and French.

The Mahabharata has its own space with its own models and traditions, and so do its recreations. The enormity and universality of the text come from the Mahabharata itself anarchically shattering the norms that it itself asserts and then rearranging the fragments. The epic holds a mirror to the diseased society through the fratricidal war for the throne of Hastinapur between the Kauravas and the Pandavas. It endeavours what can ensue in the future when the milieu is of ever-changing ethics and understanding. That is why it is not so much a narrative of war but a negation of it as a mechanism for establishing peace.

"Every great work of literature is either the Iliad or the Odyssey" (Queneau 1). The Iliad is set in Mycenaean Greece in about 760-710 B.C., during the Bronze Age. The Iliad is sometimes referred to as the 'Song of Ilium' or the 'Song of Ilion' (Troy). "A whole war, one which lasted for ten years, was fought over Helen" (Bell), portrays the epic battle between the Trojans and the Greeks in which the city of Troy crumbled into dust. The work is grandeur and propelled by character; this becomes the sole reason that characters like Achilles, Odysseus, Hector, and Paris still hold a universal appeal.

The Iliad began as shattered compositions of various kinds that eventually combine and became perfectly interwoven to form the two lengthy stories: (i) one describing the tragedy of a single place, Troy, which is fought over by many men; (ii) the homecoming adventures of a single man, Ulysses, who makes his way back through many dangerous places. For Homer, Troy came to stand for all cities and its characters epitome for every man.

Since the narrative is about men, the characters of the Iliad brings out the sense of the human situation as "a city besieged" with all the poignancy of its context. "As the generations of leaves" (The Iliad VI) the generations of men would be eradicated and death would wipe out man from human memory. Hence, against the enormous forces of life, the characters set 


\author{
21 - 23 JUNE 2019 \\ VIENNA, AUSTRIA
}

themselves to make the utmost of their human nature and achieve nobility through their prudent actions and human sentiments to attain permanence. The characters created value for themselves, within the given context, in the ideal of physical heroism.

'The proper study of mankind is man', this Greek concept underlies the all-pervasive concern with man in the classical Greek literature and the Iliad is no exception to it. Though it is true that there are frequent appearances of and intervention by Gods and Goddesses, for instance, Apollo, Arcs, Aphrodite, Eris, Doris, Hades, Hera, Hermes, Nercus, Proteus, Thetis, Zeus etc., as also some monsters and miracles, in the Iliad and the Odyssey, it is felt that they are adequately humanized. They not only inter-marry with humans but also sympathize with them and participate in their joys and sorrows. As a result, the Gods are men and men are Gods.

In the Mahabharata and the Iliad, war induces stimulating wisdom of valuable human personas such as valor, beauty, fidelity, and solidarity with utmost emotional potentiality. Though separated by miles, though they were the products of different cultures, though the settings and nations were different, when their works spoke similarly it edifies the fact that human race cannot be separated by boundaries.

Thus, when mythologies are looked upon across an array of cultures, certain resemblances based on themes, symbols and divine beings can be observed. Indra of India and Zeus of Greek are such divinities that seem to have many comparisons. Indra and Zeus are among the most authoritative God according to Vedas and Greek mythology. Prominent similarities can be found when taken into consideration their birth, appearance, romances, valor in terms of physical as well as spiritual conducts, immortality and adventures. Both are allied with rain, thunder, lightning, and figures of protectors with utmost authority. Both have surreal charms, enclosed by earthly women, showcase sentiments of love, envy and rage. As Max Muller puts in:

Nowhere is the wide distance which separates the ancient poems of India from the most ancient literature of Greece more clearly felt than when we compare the growing myths of the Vedas with full grown and decayed myths on which the poetry of Homer is founded. The Veda is the real Theogony of the Aryan races, while that of Hesiod is a distorted caricature of the original image. The fact that certain chief gods were common to all of them would lend weight to the view that the earliest hymns of the Aryans may have constituted the nucleus for many Greek, Celtic, and Persian myths. (Zimmer 193)

Taking into consideration the birth of both the heroes Indra and Zeus, Indra is born to mother earth and Zeus to Rhea the Earth Goddess. But, both are raised by substitutes, that is they are kept concealed until they materialize as fully matured and authoritative men who were able to seek revenge and bestow righteousness. Both overpowered their parents in order to take their place as commanding Gods. Indra and Zeus, both are connected with their particular weapon namely Vajra used by Indra and Keraunos by Zeus. These weapons are sturdily allied with thunder and lighting, maximum times used in mythologies to slay numerous characters. They also correspond to celestial priest-kings and accomplish their 


\author{
21 - 23 JUNE 2019 \\ VIENNA, AUSTRIA
}

functions of autonomy and military. Mahabharata and Iliad also recount Indra's and Zeus's passionate requirements for other women, where they time and again camouflage themselves in order to seduce the objects of their aspiration. Apart from their desires and cravings for other women, their martial amalgamation with the female Goddess as their wives Indrani and Hera respectively, explains their affiliation with Earth and fertility. Even the theme of dragon slaying is common to Indra and Zeus. According to Mahabharata, Indra killed the threeheaded serpent Vritra who is also known as the giant Cobra and in Greek Mythology, son of Zeus, Herakles and Apollo are the ones associated with the killing of a dragon representing the power of natural forces. Thus, the existence of both the deities tag on a common mythological construction.

Next, in line, the enticing woman prototype is epitomized through the female characters that are marked as being beautiful, seductive and eventually responsible for bringing annihilation to her loved ones. Both, Draupadi of the Mahabharata and Helen of the Iliad seize the vital qualities of the enchantress. Both had supreme loveliness and were the most enviable women. At the time of her swayamwara, Draupadi had her suitors fight for her hand in marriage. Similarly, men who were competing to acquire the beauty of Helen through marriage were obligated to risk their lives and struggle to win her. However, the most demanding and tough part in the life of Draupadi was her allotment to the brothers in which she had to be with one brother the whole year. Jealousy factor came in as far as her husband's cousins are concerned, Duryodhana and his ninety-nine brothers were envious of the Pandavas fate in the form of Draupadi and they wanted to take it away from them. Hence, because of this factor, they vented into a family feud that lasted many years. In the midst of all this warfare, Draupadi with no fault of her own had men competing for her beauty for their possession. Contrast to Draupadi, Helen was sole handedly liable for the preliminary threat she placed many men in, all this ensuing of her exquisiteness. Further, Helen's indistinctness commences, when it is argued whether she left of her own accord or was seized by Paris.

Draupadi was shared among the Pandavas brothers because of the words of their mother Kunti who accidentally made the instructions that she be shared amongst all the brothers equally before Kunti could even realize what or who it was that she was asking her sons to share. Thus, these words of her ultimately led Draupadi to be called as a wife of five husbands. The splendor of Helen always fetched her interest of many different men who wanted her for themselves. Helen's choices made her come in the category of being sexualized. At the very outset of the epic, Helen recline towards a man other than her husband. Initially, Paris anticipates to bring Helen to troy as enslaved but finds her somewhat eager to run off from her husband and go with him. Draupadi on the other hand, restrained her sexuality since she lived with one brother in rotation around the year. Moreover, in the case of Helen, rather than following the virtuous responsibilities as a queen, she goes around her fervor and fulfills it.

Death is a common trait, which the two women are allied with in the epic, as they are accountable for bringing bereavement to numerous warriors during the course of the long war. Draupadi demonstrates a strong promoter for war during her long exile. By the end almost all, the cousins including uncles and father figures depart their lives at the hands of the Pandavas 
who fought for Draupadi. In due course, Draupadi plays an imperative role in the death of many warriors through her attachment with the brothers. Similarly, Helen was well conscious from the beginning that Menelaus would never leave her and bring destruction if she ever chooses to leave him; even then, she pays no attention to the consequences. She returns with Aphrodite to Paris but rebukes Paris for not being as sturdy as a warrior is Menelaus. Thus, may be her decision about the war may be indefinite but she clearly brings forth the destruction and death of many warriors.

Draupadi becomes the supporter of war only after experiencing how her life with her husbands' has radically deteriorated because of the issues entrenched in the covetousness of their cousins. Thus, she believes that Duryodhana deserves to be punished after all the evil deeds he has done. Helen too is not well accepted during the epic as she acts on her obsessions and makes choices for her own self. Her departure from Sparta with Paris is fundamentally liable for the war between the Greek and Trojans that continues for years leaving almost everyone dead. Hence, both Draupadi and Helen are viewed as dynamic feminists in quest of contentment in their lives as well as of the lives of those around them.

Another character from the epics who share a substantial amount of resemblance is Arjuna and Achilles. Both the heroes are unbeatable and are viewed as extraordinary warriors in their particular battles. In Mahabharata, a devastating war begins between cousins but Arjuna does not want to act. It becomes a dangerous situation for the Pandavas particularly since the finest warrior Arjuna is unwilling to participate in the war since he doesn't want to devastate his family with his own hands. Thus, he has to be persuaded as to why his actions are obligatory and correct. Hence, Lord Krishna, the charioteer of Arjuna's horse proceeds to reinstate Arjuna's will to act by amplificating the nature of the action itself. Krishna succeeds in bringing Arjuna back and the clash thus commences. Likewise, in the Iliad, the supreme warrior of Troy is out of action. In the beginning, he is not the part of this big scuffle as he is enraged at the disrespect with which the Greek leaders had treated him. Achilles makes Agamemnon pay for this disdain and the Greeks are stuck against their own ships and endangered with total destruction. Achilles does not even cave in when one of the Greek ships is set on flames. Achilles comes back into this feud when his dearest friend Patroclus is killed, after this incident, he is unstoppable. Loss of Patroclus induces him to return in vengeance to search his friend's killer and slay him. Therefore, Krishna and Patroclus occupy a significant role in Arjuna and Achilles life and bring forth their capacities.

Both the Mahabharata and the Iliad are an investigation of human nature. It shows that prehistoric descriptions active in the ethnic unconscious of human minds. "Archetypes belong to the class of ideas that people at first find strange but soon come to possess and use as familiar conceptions. Like flutes of different origin producing the same music, human minds of different ages at approximately the same eras develop similar ideas regarding the human kind" (Jung 93). Each exhibits the divine ease with which a core idea of human emotions is studied which demonstrates that the human difficulties in every culture remain the same. 
Hence, the Iliad and the Mahabharata are grand in their vision, tell common tales of heroes of their culture and depict the same values. In spite of belonging to diverse ethnicities, they have one thing in common that they stroke the human cord. Perhaps this is the dissimilarity between literature for a generation and literature, which encourages many generations. The Iliad and the Mahabharata belong to the second kind.

\section{References}

[1] Alexander, C. (Trans.). (2016). The Iliad. U.S.A: Random House.

[2] Ali, M.M. (1991). The Koran: Holy Quran-Arabic Text, English Translation and Commentary. U.S.: Ahmadiyyah Anjuman Isha'at Islam Lahore Inc.

[3] Bassnett, S. (1993). Comparative Literature: A critical Introduction. C.A: Blackwell Publishers Ltd.

[4] Bell, R. (1996). About Helen of Troy. In P.Brunel (Author), Companion to Literary Myths, Heroes and Archetypes (p. 12). UK:Seeley.

[5] Bharati, D. (2004). Andha Yug. New Delhi: DK.

[6] Brockington, J.L. (1998). The Sanskrit Epics. Boston: Brill.

[7] Bryant, E.F. (2007). Krishna: A Sourcebook. U.S.A: Oxford UP.

[8] Campbell, J. (1976). The Masks of God: Primitive Mythology. U.S.A: Penguin.

[9] Davidson, H.R.E. (1964). Gods and Myths of Northern Europe. Baltimore: Penguin.

[10] Dubois, J. (2008). Myths, Stories \& Reality. Retrieved March 29, 2019, from www.csus.edu/indiv/d/duboisj/wm/wm_msr.html.

[11] Duffy, J. (1937). A Comparative Study of the Religion of the Iliad and Odyssey. U.S: Michigan UP.

[12] Edmunds, L. (2015). Stealing Helen: The Myth of the Abducted Wife in Comparative Perspective. New Jersey: Princeton UP.

[13] Ganguly, K.M (Trans.). (2002). The Mahabharata of Krishna Dwaipayana Vyasa. Ontario: Cambridge Press.

[14] Graves, R. (1992). The Greek Myths. London: Penguin.

[15] Hawkins, T. (2009). The Rage of Achilles. C.A: Casperian Books.

[16] Hitlebeitel, Alf. (1991). The Cult of Draupadi: mythologies: from Ginger to Kurukserta. New Delhi: Motilal Banarsidass Publishers.

[17] Huberman, E.A. (1996). A Note on the Multi-cantered Imagination of the Mahabharata. Journal of Vaishanava Studies, 4(3), pp. 65-84. Retrieved March 27, 2019, from http://www.deepakhertiage.com/contents/4-3-toc.pdf. 
[18] Hudson, E.T. (2013). Disorientating Dharma: Ethics and the Aesthetics of Suffering in the Mahabharata. New Delhi: Oxford UP.

[19] Iliffe, Glyn. (2011). The Armour of Achilles. London: Pan Macmillan.

[20] Jung. C. (n.d.). A Study in the Process of Individual. Psychology and Alchemy, pp. 93.

[21] Karnad, K. (2007). Yuganta. New Delhi: Oxford UP.

[22] Max, M. (1909). Comparative Mythology: An Essay. London: Routledge.

[23] Myth. (2003). In S.M . Murfin (Ed.), In the Bedford Glossary of Critical and Literary Terms. (p. 284). Boston: Bedford Martin.

[24] Nelson, T. (2009). Holy Bible, New King James Version (NKJV). U.S.A: Thomas Nelson.

[25] Parmar, A.K. (2002). Critical Perspectives on the Mahabarata. New Delhi: Sarup \& Sons.

[26] Prawer, S. (1973). Themes and Prefigurations.In Comparative Literary Studies- An Introduction (p. 55). London: Gerald Duckworth \& Co. Ltd.

[27] Queneau, R. (2005). Bouvard et Pecuchet [Preface]. In G. Flaubert (Author), Bouvard et Pecuchet (p.1). U.S: Dalkey Archive Press.

[28] Righter, W. (1975). Myth and Litertaure. London: Routledge.

[29] Rodrigues, H. (2006). Introducing Hinduism. London: Routledge.

[30] Sanyal, A.K. (2006). The Wonder That is the Mahabharata. Bulletin of the Ramakrishna Mission Institute of Culture, 57(4), pp. 195-199.

[31] Schein, S.L. (1984). The Mortal Hero: An Introduction to Homer's Iliad. U.S.A: California UP.

[32] Smith, H. (1991). The World's Religions: Our Great Wisdom Traditions. California: Harper Collins.

[33] Zimmer, H.R. (1992). Myths and Symbols in Indian Art and Civilization. New Jersey: Princeston UP. 